\title{
Closed reduction of humeral condylar fracture and elbow luxation in a dog
}

\author{
Reducción cerrada de fractura condilar de húmero y luxación de \\ codo en un canino
}

\author{
Sebastián Cardona R, ${ }^{1}$ MVZ, Luis-Carlos Muñoz R, ${ }^{1}$ MVZ, Raúl-Fernando Silva M, ${ }^{1 *}$ Ph.D. \\ Universidad de Caldas, Facultad de Ciencias Agropecuarias, Grupo de investigación Terapia \\ Regenerativa, A.A Nro. 275, Manizales, Colombia. *Correspondencia: raul.silva@ucaldas.edu.co
}

Received: August 2014; Accepted: February 2015.

\begin{abstract}
Fractures of the distal humerus that involving the condyles often requires extensive surgical approach for treatment, leading to a prolonged recovery time. In a West Highland White Terrier dog two years old, with a fracture of the lateral humeral condyle portion and elbow luxation, was performed a closed technique for luxation reduction, fracture reduction was performed by digital pressure and percutaneous osteosynthesis by introduction of a Kirschner wire of $2 \mathrm{~mm}$ diameter, accompanied by Robert-Jones bandage modified for 6 weeks. Limb function was recovered in the immediate postoperative, the wire was removed six weeks after, non-was observed postoperative complications, and full functional recovery of the limb was clinically evident. This suggests that this technique could be an option in cases of condylar fractures in small-sized dogs.
\end{abstract}

Key words: Dog, fixation, orthopedics (Source: $C A B$ ).

\section{RESUMEN}

Las fracturas de la porción distal del húmero que involucran los cóndilos, frecuentemente exigen para su reparación un amplio abordaje quirúrgico, que conlleva un tiempo de recuperación prolongado. En un canino West Highland White Terrier de dos años de edad, con una fractura de la porción lateral del cóndilo humeral y luxación de codo, se realizó una técnica cerrada de reducción de la luxación, reducción de la fractura mediante presión digital, y osteosíntesis percutánea mediante la introducción de un clavo de kirschner de $2 \mathrm{~mm}$ de diámetro, acompañado de vendaje de Robert-Jones modificado durante 6 semanas. El paciente recuperó la función del miembro en el posquirúrgico inmediato, no se evidenciaron complicaciones posquirúrgicas, seis semanas después se retiro el clavo y se evidenció clínicamente recuperación total de la funcionalidad del miembro. Lo anterior sugiere que esta técnica podría ser una opción en casos de fracturas condilares en perros de pequeño porte.

Palabras clave: Fijación, ortopedia, perro (Fuente: $C A B$ ). 


\section{INTRODUCTION}

The humerus fractures make up almost $10 \%$ of all appendicular fractures (1). Almost half of the humerus fractures $(46.6 \%)$, occur in the distal aspect (2). Of these fractures, the humeral condyle is relatively frequent (2).

The reduction of condylar fractures is usually made with wide surgical approaches that allow for the visualization of all structures. These approaches include a portion of the ulnar-humerus of the el joint elbow by osteotomy of the olecranon or by tenotomy of the triceps tendon, among others (3). As a result, the reduction of condyle fractures shows a high incidence in post surgical complications, among which are the reduction of the range of the articular movement and osteoarthritis of the elbow, among others (4).

As a result, the application of biological osteosynthesis concepts (5), through the use of Kirschner wires in a minimally invasive way, can offer great advantages with respect to traditional techniques, such as less postoperative pain, fast healing and less iatrogenic trauma to important structures such as the physes and the articular capsule.

The closed reduction of a lateral traumatic luxation of the humerus-radius-ulnar is described below. The reduction is performed by digital pressure of a fracture of the lateral portion of the condylar humeral and the fixation through the precutaneous application of a Kirschner wire to a canine patient.

\section{CLINICAL CASE}

The patient was a West Highland White Terrier dog, adult, two years old and 7.4 kilograms of body mass, that went to consultation after 96 hours of suffering a fall from a height of 3 meters, with severe claudication of the right thoracic limb characterized by lack of support and total absence of articular mobility.

$X$-rays were made in the medium-lateral and the crown-rump length projections evidencing lateral luxation of the humerus-radius-ulnar articulation and the condylar fracture of the lateral aspect of the humeral condyle (Figure 1).

Because the owner did not have the financial resources to pay for the cost of the treatment through open reduction and internal fixation, and since the owner had to travel quickly to a remote location with no veterinary service available, it was decided to perform an ambulatory treatment. Through traction and counter-traction maneuvers

\section{INTRODUCCIÓN}

Las fracturas humerales corresponden a cerca del $10 \%$ de todas las fracturas apendiculares (1). Casi la mitad de las fracturas de húmero $(46.6 \%)$, ocurren en el aspecto distal (2). De estas, las fracturas de los cóndilos humerales son relativamente frecuentes (2).

La reducción de las fracturas condilares usualmente se realiza con abordajes quirúrgicos amplios, que permitan visualizar todas las estructuras. Dentro de las cuales se incluyen abordaje de la porción humero-ulnar de la articulación del codo por osteotomía del olecranon o por tenotomía del tendón del tríceps entre otras (3). Debido a lo anterior, la reducción de fracturas condilares presenta una alta incidencia de complicaciones posquirúrgicas, dentro de las cuales se presenta disminución del rango de movimiento articular y osteoartritis del codo entre otras (4).

Debido a lo anterior, la aplicación de los conceptos de osteosíntesis biológica (5), mediante el uso de clavos de kirschner de una manera mínimamente invasiva puede ofrecer grandes ventajas con respecto a las técnicas tradicionales, como menor dolor posoperatorio, cicatrización rápida y menor trauma iatrogénico a estructuras importantes como las fisis y la cápsula articular.

A continuación se describe la reducción cerrada de una luxación traumática lateral de la articulación humero-radio-ulnar, reducción mediante presión digital de una fractura de la porción lateral del cóndilo humeral y fijación mediante aplicación percutánea de un clavo de kirschner, en un paciente canino.

\section{CASO CLÍNICO}

El paciente era un canino de raza West Highland White Terrier, macho entero, de dos años de edad y 7.4 kilogramos de masa corporal, que se presentó a consulta después de 96 horas de sufrir una caída desde una altura aproximada de 3 metros, con claudicación severa del miembro torácico derecho caracterizada por no apoyo y ausencia total de movilidad articular.

Se realizaron radiografías en las proyecciones medio-lateral y cráneo-caudal evidenciando luxación lateral de la articulación humeroradio-ulnar y fractura condilar del aspecto lateral del cóndilo humeral (Figura 1). 


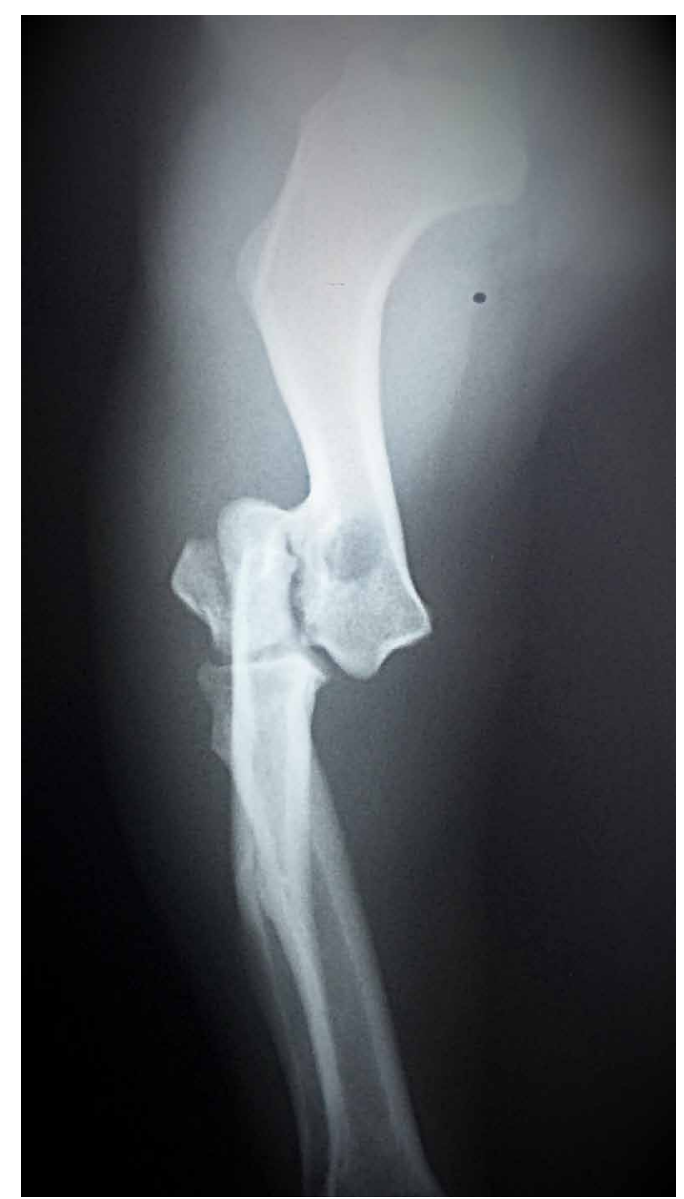

Figure 1. CRL x-ray shows lateral luxation of the elbow and condyle fracture of the lateral aspect of the humeral condyle in a dog patient of West Highland White Terrier breed, two years old and 7,4 kilograms of body mass, after 96 hours of suffering a fall from a height.

a closed reduction of the luxation was performed and, through the Campbell evaluation method, it was determined that the collateral ligaments were intact (6).

The surgical treatment consisted in a closed reduction of the fracture of the lateral aspect of the humeral condyle by digital pressure. A Kischner wire of $2 \mathrm{~mm}$ was introduced by percutaneous access through the lateral fractured aspect, intercondylar until the medial aspect of the humeral condyle, as the only method of fixation (Figure 2). Later, the dog was immobilized with Robert-Jones bandage that was modified during four months.

\section{RESULTS}

Limb function was recovered in the immediate postoperative. When the patient recovered his conscience, he started to wander with moderate
Debido a que el propietario no contaba con los recursos financieros para costear el tratamiento mediante reducción abierta y fijación interna, y a que se tenía que desplazar rápidamente a una población lejana donde no contaba con servicio veterinario. Se decidió instaurar tratamiento ambulatorio. Mediante maniobras de tracción y contra-tracción se realizó reducción cerrada de la luxación y mediante el método de evaluación de Campbell se determinó que los ligamentos colaterales estaban intactos (6).

El tratamiento quirúrgico consistió en reducción cerrada de la fractura del aspecto lateral del cóndilo humeral mediante presión digital. Se introdujo vía percutánea a través del aspecto lateral fracturado un clavo de kischner de 2 $\mathrm{mm}$, intercondilar hasta el aspecto medial del cóndilo humeral, como único método de fijación (Figura 2). Posteriormente, se inmovilizó mediante vendaje de Robert-Jones modificado durante cuatro semanas.

\section{RESULTADOS}

El paciente recuperó la función del miembro en el posquirúrgico inmediato, tan pronto como recuperó la conciencia, comenzó a deambular con claudicación moderada del miembro tratado. No se evidenciaron complicaciones posquirúrgicas durante las seis semanas de acompañamiento clínico. Cuatro semanas después se retiro el clavo, se evidenció clínicamente recuperación satisfactoria de la funcionalidad. El vendaje de Robert Jones modificado fue retirado definitivamente a las seis semanas. Los ángulos de extensión y flexión de la articulación afectada fueron 150 y 40 grados, y los de la articulación contralateral fueron de 154 y 30 grados, respectivamente, radiográficamente no se encontraron signos compatibles con osteoartritis de la articulación (Figura 3).

\section{DISCUSIÓN}

Si bien, el objetivo fundamental en el tratamiento de fracturas de los cóndilos humerales es restablecimiento de la superficie articular y fijación y estabilización del cóndilo a la diáfisis humeral (7). En casos donde no se puede realizar reducción abierta y fijación interna (RAFI) para permitir una rápida movilización de la articulación, el tratamiento quirúrgico es contraproducente (8). En el presente relato de caso ante la imposibilidad de realizar RAFI se realizó reducción cerrada 
claudication of the treated limb. No postsurgical complications appeared during the six weeks of clinical support. Four weeks after the removal of the wire, a satisfactory clinical recovery of the functionality of the limb was evidenced. The Robert Jones modified bandage was removed definitively at six weeks. The extension and bending angles of the affected joint were 150 and 40 degrees, and the angles of the contralateral joint were 154 and 30 degrees, respectively; in the x-rays, no compatible signs with osteoarthritis of the joint were found (Figure 3).

\section{DISCUSSION}

Although the main objective of the treatment of fractures in the humeral condyles is to restore the join surface and fixation and the stabilization of the condyle to the humeral dyaphisis (7), in cases

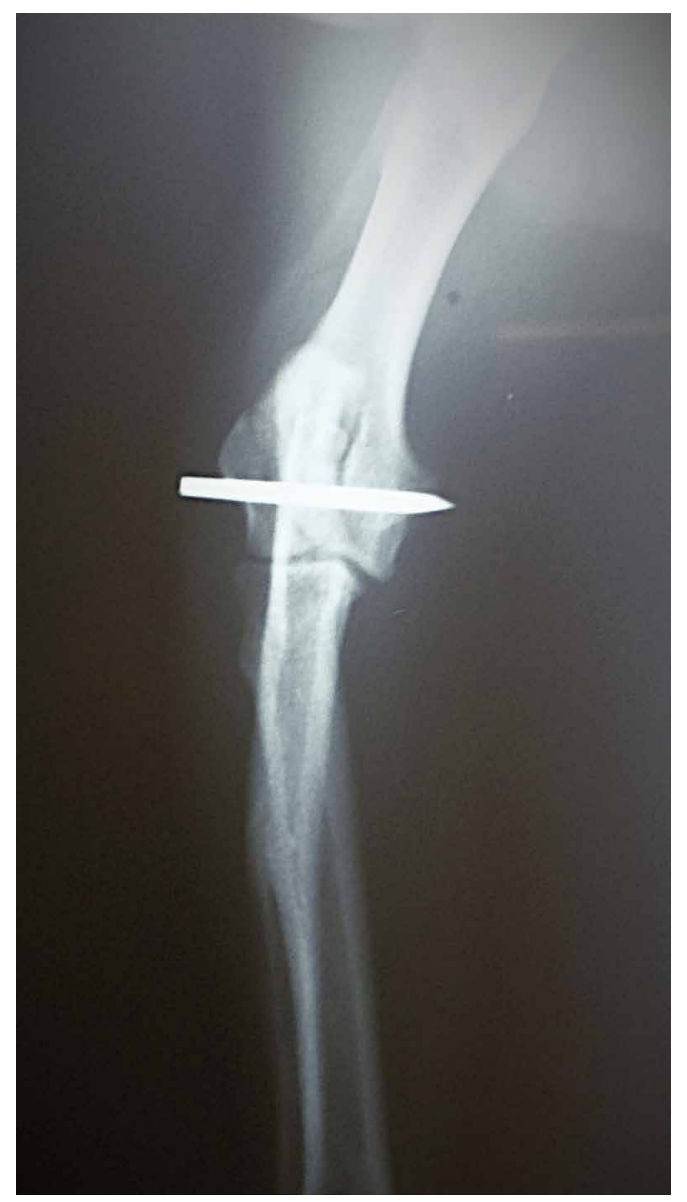

Figure 2. CRL $x$-ray that shows a closed reduction of the luxation and the lateral aspect fracture of the humeral condyle by a $2 \mathrm{~mm}$ Kischner wire, intercondylar until the medial aspect of the humeral condyle.

\section{e inmovilización externa como alternativa de tratamiento.}

En la actualidad una de las técnicas mas utilizadas es aplicar un tornillo para lograr compresión interfragmentaria y conseguir cicatrización primaria de la fractura (7). Si bien, la aplicación de un clavo no produce compresión interfragmentaria, lo cual podría derivar en que no ase consiga total congruencia articular y complicaciones como mala unión o no unión, en el presente caso este tipo de complicaciones no se evidenciaron, y clínicamente durante la evaluación subjetiva de la marcha se observo evolución de claudicación severa (perdida de función) a no presencia de claudicación, lo que permite especular con que el tratamiento instaurado no las produjo.

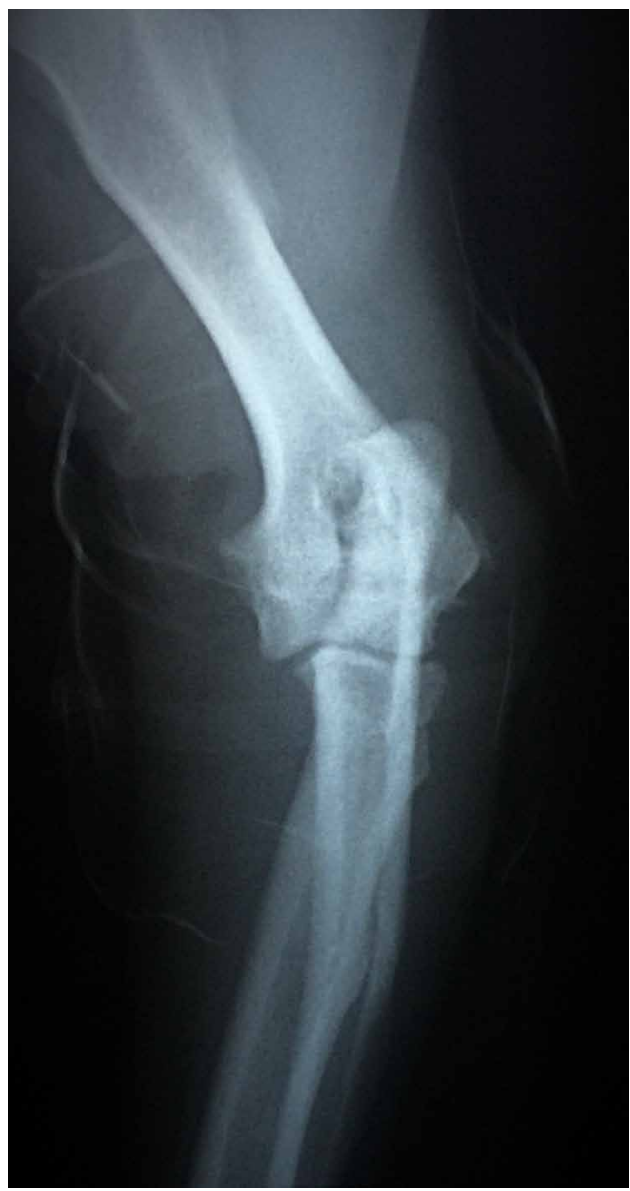

Figure 3. $C R L$-ray that shows the elbow joint 4 weeks after the surgical treatment at the moment in which the Kischner wire was removed, even with the modified Robert Jones bandage still on for two more weeks. 
were an open reduction and internal fixation (RAFI) cannot be performed to allow a fast mobilization of the joint, the surgical treatment is counterproductive (8). In this case, since the RAFI treatment could not be preformed, a closed reduction and external immobilization was performed as an alternative treatment.

Currently, one of the most used techniques is to apply a screw to obtain interfragmentary compression and primary healing of the fracture (7). Although in this case the application of a wire does not produce interfragmentary compression, which could cause the nonoccurrence of joint congruence and even complications such as bad union or non union, in this case, no complications were evidenced during the evaluation period and clinically, during the subjective evaluation, there was an evolution from severe claudication (loss of function) to no claudication. This allows speculating that the performed treatment did not cause it.

Although RAFI is performed to ensure anatomic alignment of the joint surface, a high incidence of complications has been reported, including claudication, osteoarthritis, non-union, osteomyelitis and loss of movement range, among others (9). It is reported that between $28-57 \%$ of the dogs that were subjected to a reduction of the fracture of the humeral condyle, had long-term claudication and loss of the function of the affected limb (2).

The traditional method of reduction of fractures known as anatomic reconstruction (10), offers disadvantages with respect to biological osteosynthesis, such as prolonged surgery time, excessive retraction and alteration of the soft surrounding tissue (11). This not only limits the extra osseous blood supply necessary for the formation of the callus $(10,12)$, but it also reduces the transfer of mononuclear cells; which could not only affect the healing time but could also compromise the resistance to infection and increase the probabilities of bacteria contamination. Unlike the biological osteosynthesis concepts (5), which include the fixation of fractures without altering surrounding soft tissues and the periosteum (12), which among others, the treatment offers advantages such as the preservation of the potential osteogenic of the bruising of the fracture $(10,13)$, which promotes the osseous regeneration and reduces healing and recovery time (10). In this case, given the impossibility to perform RAFI, the biological osteosynthesis concepts were applied as alternative treatment.

Since no kinetic and/or kinematic methods were available to measure the objective degree of claudication, goniometry was used as an indirect indicator of the degree of joint functionality. This method has been widely used by orthopedics and physiotherapies on humans to quantify the limits
Aunque la RAFI se realiza para asegurar el alineamiento anatómico de la superficie articular, se ha reportado alta incidencia de complicaciones, que incluyen claudicación, osteoartritis, no unión, osteomielitis y pérdida del rango de movimiento, entre otros (9). Se reporta que entre el $28-57 \%$ de perros que fueron sometidos a reducción de fractura del cóndilo humeral tuvieron claudicación a largo plazo y pérdida de la función del miembro afectado (2).

El método tradicional de reducción de fracturas conocido como reconstrucción anatómica (10), ofrece desventajas con respecto a la osteosíntesis biológica, como tiempo de cirugía prolongado, requiere retracción excesiva y alteración del tejido blando circundante (11), lo cual no sólo limita el suministro sanguíneo extra óseo necesario para la formación del callo $(10,12)$, sino que disminuye la transferencia de células mononucleares; lo que no sólo podría afectar el tiempo de cicatrización sino comprometer la resistencia a la infección y aumentar las posibilidades de contaminación bacteriana $(10,12)$. A diferencia de los conceptos de osteosíntesis biológica (5), que incluyen fijación de fracturas sin alterar los tejidos blandos circundantes y el periostio (12), que entre otras ofrece ventajas como la preservación del potencial osteogénico del hematoma de la fractura $(10,13)$, lo cual promueve la regeneración ósea y disminuye el tiempo de cicatrización y de convalecencia (10). En este caso ante la imposibilidad de realizar RAFI se optó por aplicar los conceptos de osteosíntesis biológica como alternativa de tratamiento.

Al no disponer de métodos cinéticos $\mathrm{y} / \mathrm{o}$ cinemáticos, para medir objetivamente el grado de claudicación, se opto por realizar como indicador indirecto del grado de funcionalidad articular la goniometría, que ha sido utilizada ampliamente por ortopedistas y fisioterapeutas humanos para cuantificar los límites de los movimientos de las articulaciones, determinar el grado de pérdida de función, como ayuda diagnóstico, toma de decisiones terapéuticas y control pos tratamiento. En ortopedia canina, se ha utilizado la goniometría para evaluar la eficacia del tratamiento, en alteraciones que involucran enfermedades articulares y ha mostrado una gran confiabilidad (14). En este sentido, existen reportes de disminución de los ángulos de flexión y extensión de la articulación del codo en caninos sometidos a cirugía (7). Si bien, los valores reportados para los ángulos de flexión y extensión del codo oscilan alrededor de $20^{\circ}$ y $170^{\circ}$ respectivamente (15), 
of joint movements, determine the degree of loss of function, as a diagnosis aid, to make therapeutic decisions and post treatment control. In canine orthopedist, goniometry has been used to evaluate the efficiency of the treatment in alterations involving joint diseases and it has shown great reliability (14). In this sense, there are reports about the reduction of flexibility and extension degrees of elbow joints in canines subjected to surgery (7). Even though the reported values for flexibility and extension degrees of the elbow range between $20^{\circ}$ and $170^{\circ}$ respectively (15), the estimated values for this case for elbow joint in flexibility and extension were $40^{\circ}$ and $150^{\circ}$ in flexibility and extension, but the normal contralateral joint values were of $38^{\circ}$ and $154^{\circ}$, respectively. This indicates that the patient recovered a range of mobility close to normal during the evaluation period.

Even though this case presents limitations with respect to diagnostic aids, objective clinical evaluation and the treatment differs from the ideal treatment, in a country with socioeconomic conditions like ours were the ideal economic, technical and logistic conditions for the diagnosis and treatment of certain conditions are not always available, its important to offer therapeutic alternatives different from the natural course of the disease and improve the final result of this evolution, possibly based in body mass and zoo technical attitude of the patient and technical and economical limitations.

The results obtained in this case suggest that the closed reduction of this type of fractures in the procedures described in this clinical case could be considered as an alternative for the treatment of this type of fractures in small dogs. los valores encontrados en este caso para la articulación del codo afectada fueron de $40^{\circ}$ y $150^{\circ}$ en flexión y extensión, pero los valores de la articulación contralateral normal fueron de $38^{\circ}$ y $154^{\circ}$, respectivamente. Lo cual indica que el paciente recuperó un rango de movilidad cercano a la normalidad, durante el tiempo de evaluación.

Si bien, el presente relato de caso presenta limitaciones respecto a ayudas diagnosticas, evaluación clínica objetiva y el tratamiento discierne de lo considerado como ideal, en un país con condiciones socioeconómicas como el nuestro donde no siempre se cuentan con las condiciones económicas, técnicas y logísticas ideales para el diagnóstico y tratamiento de ciertas afecciones, es importante ofrecer alternativas terapéuticas diferentes al curso natural impredecible de la enfermedad y mejorar el resultado final de la evolución de esta, posiblemente basadas en la masa corporal y actitud zootécnica del paciente, y limitantes técnicas y económicas.

Los resultados obtenidos en este caso, sugieren que la reducción cerrada de este tipo de fracturas y los procedimientos descritos en este caso clínico, podrían considerarse una alternativa para el tratamiento de este tipo de fracturas en perros de pequeño porte.

\section{REFERENCES}

1. Johnson JA, Austin C, Breur GJ. Incidence of canine appendicular musculoskeletal disorders in 16 veterinary teaching hospitals from 1980 through 1989. Vet Comp Orthop Traumatol 1994; 7(2):56-69.

2. Bardet JF, Hohn RB, Rudy RL, Olmstead ML. Fractures of the humerus in dogs and cats: a retrospective study of 130 cases. Vet Surg 1983; 12(2):73-77.

3. Simpson A M. Fractures of the humerus. Clin Tech Small Anim Pract 2004; 19(3):120-127.

4. Gordon WJ, Besancon MF, Conzemius MG, Miles KG, Kapatkin AS, Culp WTN. Frequency of post-traumatic osteoarthritis in dogs after repair of a humeral condylar fracture. Vet Comp Orthop Traumatol 2003; 16(1):1-5.
5. Beale, B. Orthopedic clinical techniques femur fracture repair. 2004. Clin Tech Small Anim Pract 2004; 19(3):134-150.

6. Bordelon JT, Reaugh HF, Rochat MC. Traumatic luxations of the apendicular skeleton. Vet Clin Small 2005; 35 (5):1169-1194.

7. Moores A. Humeral condylar fractures and incomplete ossification of the humeral condyle in dogs. In Practice 2006; 28(7):391-397.

8. Schatzer J. The rationale of operative fracture care. Third edition, Springer Berlin Heidelberg New York - USA. 2005; p. 34-35.

9. Kim S E, Hudson C C, \& Pozzi A. Percutaneous Pinning for Fracture Repair in Dogs and Cats. 2012. Vet Clin North Am Small Anim Pract 2012; 42(5):963-974. 
10. Horstman CL, Beale BS, Conzemius MG, Evans R. Biological Osteosynthesis Versus Traditional Anatomic Reconstruction of 20 Long-Bone Fractures Using an Interlocking Nail: 1994-2001. Vet Surg 2004; 33(3):232-237.

11. McKee W M, Macias C \& Innes J F. Bilateral fixation of Y-T humeral condyle fractures via medial and lateral approaches in 29 dogs. J Small Anim Prac 2005; 46(5):217-226.

12. Broos PLO, Sermon A. From unstable internal fixation to biological osteosynthesis. A historical overview of operative fracture treatment. Acta Chir Belg 2004; 104(4):396-400.
13. Kolar P, Schmidt-Bleek $K$, Schell H, Gaber T, Toben D, Schmidmaier G, Perka C., et al. The early fracture hematoma and its potential role in fracture healing. Tissue Eng Part B Rev 2010; 16(4):427-434.

14. Lamoreaux Hesbach A. Techniques for objective outcome assessment. Clin Tech Small Anim Pract 2007; 22(4):146-154.

15. Millis D \& Levine D. Appendix 2. Joint motion and ranges. 2nd edition. En: Canine rehabilitation and physical therapy. Philadelphia, PA: Elsevier. 2014 